\title{
Acerola shoot proliferation induced by a phytoplasma enclosed in the subgroup $16 \mathrm{Srlll}-\mathrm{F}$
}

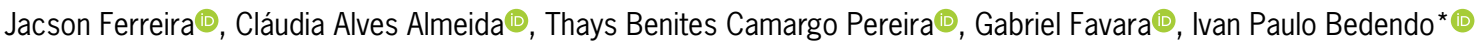

Universidade de São Paulo/ESALQ - Depto. de Fitopatologia e Nematologia, C.P. 09 - 13418-900 - Piracicaba, SP Brasil.

*Corresponding author <ibedendo@usp.br>

Edited by: Paulo Cesar Sentelhas

Received October 09, 2020

Accepted January 31, 2021
ABSTRACT: Acerola bushes were observed showing symptoms of shoot proliferation, generalized stunting, yellowing and decline. Since these symptoms are typically induced by phytoplasmas, this survey was carried out with the aim of detecting, identifying and classifying the supposed phytoplasma present in symptomatic bushes. Total DNA was extracted from symptomatic and asymptomatic samples and used in nested PCR conducted by the primer pairs R16mF2/mR1 followed by R16F2n/R2. Amplifications of expected genomic fragments of $1.2 \mathrm{~kb}$ revealed the presence of phytoplasma in $73 \%$ of the symptomatic samples. Molecular analyses, using computer-simulated RFLP patterns, similarity coefficient calculation and phylogenetic analysis allowed for classifying the bacterium as a 'Candidatus Phytoplasma pruni' - related strain (subgroup 16Srll-F). The phytoplasma induced the same symptoms in healthy acerola plants inoculated by grafting and showed molecular identity with the strain identified in naturally infected bushes. Although various strains belonging to distinct subgroups within the $16 \mathrm{Sr}$ rll group have been previously identified in Brazil, this is the first report of the presence of a representative of the 16Srlll-F subgroup in the Brazilian agroecosystem. Considering that phytoplasmas can be systemically distributed throughout the plant and acerola plants are vegetatively propagated, it is recommended that propagation material be obtained from mother plants free of the pathogen. Keywords: Malpighia emarginata, bacteria, phytopathogenic mollicutes, yellows disease, wallless prokaryote

\section{Introduction}

Acerola (Malpighia emarginata DC) is a bush belonging to the Malpighiaceae family, a native species of South and Central America (Leffa et al., 2014; Silva et al., 2019). The fruit presents medicinal properties containing high antioxidant activity, substantial amounts of ascorbic acid, and mineral compounds (Chang et al., 2018). In Brazil, acerola has been commercially exploited from the early 1980 s as a result of high commercial demand, making the country the world's largest producer and exporter (De Rosso and Mercadante, 2005). The United States of America, Japan and several European countries have a considerable demand for products based on acerola, mainly due to its high vitamin C content (De Rosso and Mercadante, 2005).

Phytoplasmas are wall-less prokaryotes, phloem inhabitants, spread and transmitted by insect vectors. These obligate intracellular bacteria are associated with numerous diseases found in several hundred plant species, inducing, in the main, symptoms of shoot proliferation, phyllody, yellowing and generalized stunting (Bertaccini et al., 2014). Molecular identification was carried out on the basis of analyses of conserved genes, mainly nucleotide sequences of the gene 16S rRNA (Wei et al., 2008). In addition, since phytoplasmas can be transmitted through grafting (Lee et al., 2000), biological assays were performed in order to verify their role and transmissibility in the disease.

\section{Materials and Methods}

The present study deals with acerola plants that exhibited symptoms possibly induced by phytoplasmas characterized by shoot proliferation, generalized stunting, yellowing and decline. The disease reduces the normal growth and the quantity and quality of fruit, as well as delaying production.

Samples of leaves and shoots from 11 symptomatic and two asymptomatic bushes were collected and the total DNA was extracted following a prescribed protocol (Doyle and Doyle, 1990).

Phytoplasma detection was performed by nested PCR primed by the pairs R16mF2/mR1 followed by $\mathrm{R} 16 \mathrm{~F} 2 \mathrm{n} / \mathrm{R} 2$, as described in the literature (Gundersen and Lee, 1996). DNA from periwinkle plants knowingly infected by 16SrIII phytoplasma (GenBank GU193977 Flôres et al., 2013) were used as the positive control and healthy acerola plants represented the negative control.

The DNA products amplified by nested PCR were cloned into Escherichia coli DH5 $\alpha$. Sequences corresponding to the $16 \mathrm{~S}$ rRNA gene of phytoplasmas from four samples were sequenced (three clones for each sample) using the SP6/T7 primers (Malembic-Maher et al., 2008). The sequences were aligned, compared against themselves and phytoplasma sequences found in GenBank employing the Bioedit DNA analysis programs. A majority consensus sequence was selected as reference for the phytoplasma identified in acerola plants and sequences of phytoplasmas belonging to distinct subgroups within the 16SrIII group, deposited in the GenBank database, were submitted to computer-simulated analysis with a set of 17 restriction enzymes, as described by Wei et al. (2008). Based on the colletive restriction profiles a similarity coefficient $(\mathrm{F})$ was calculated for each pair of phytoplasmas considering the strain representative of the acerola phytoplasma and phytoplasmas enclosed 
in subgroups of the 16 SrIII group. Additionally, the majority consensus sequence representative of the phytoplasma present in acerola plants was also submitted to the interactive online tool iPhyClassifier (Zhao et al., 2009). A phylogenetic tree was constructed with the sequence of the acerola phytoplasma and sequences from representatives of the diverse ribosomal subgroups belonging to the 16SrIII group, using the MEGA 6.0 program (Tamura et al., 2013). The nucleotide sequence of Acholeplasma palmae was used as the outer root of the tree. The phylogenetic tree was built using the 'Neighborjoining' method and 'bootstraping' processed 1,000 times.

A transmission test was carried out with 15 acerola rootstocks cultivated in pots, 18 months old, generated from branches of a mother plant, and previously submitted to nested PCR in order to verify the absence of phytoplasmas. The scions approximately $2 \mathrm{~cm}$ long were collected from symptomatic trees proven to be harbouring the phytoplasma and grafted onto the potted plants. Samples were collected from grafted symptomatic plants maintained in a greenhouse with screens to avoid insects, and the total DNA was used in nested PCR. The detected phytoplasma was molecularly identified by sequencing the $16 \mathrm{~S}$ rRNA gene and computer-simulated analysis.

Further assays were conducted in order to verify the presence of virus in the acerola samples. The RNA extracted with a Purelink viral RNA/DNA kit was used in RT-PCR (Reverse Transcription-Polymerase Chain Reaction) for detecting cucumber mosaic virus (CMV) and the virus belonging to the Potyvirus and Begomovirus genera. The RT-PCR reactions for CMV were performed according to a protocol previously described by Rizos et al. (1992). The assays for detecting Potyvirus were carried out with primers CIFor/CIRev (Ha et al., 2008), while the RT-PCR reactions for Begomovirus were primed by the PAL/PAR pair (Rojas et al., 1993).

\section{Results and Discussion}

The association of phytoplasma with affected plants was demonstrated by the amplification of expected genomic fragments of approximately $1.2 \mathrm{~kb}$ from the nested PCR. These were detected in $73 \%$ of the analyzed samples (Figure 1). PCR assays yielded products from positive control, but there was no amplification from the negative control. The RT-PCR generated no product, thereby indicating the absence of virus in the analyzed samples.

The sequence selected to represent the phytoplasma identified in the acerola bushes was denominated ASPBr01 (Acerola Shoot Proliferation-Brazil 01) and deposited in the GenBank database under accession number MT153591. This sequence shared $99.6 \%$ identity with sequences of $16 \mathrm{~S}$ rRNA of 'Candidatus Phytoplasma pruni'-related strains. The analysis by the interactive tool online iPhyClassifier indicated that the acerola phytoplasma belongs to the 16 SrIII-F subgroup (Figure $2)$. The identity between ASP-Br01 phytoplasma and the phytoplasma of the 16SrIII-F subgroup (Genbank accession number AF510724) was confirmed since the similarity coefficient $(\mathrm{F})$ value was 1.0. Phylogenetic analysis was consistent with the computer-simulated RFLP analysis because the branching pattern of the phylogenetic tree showed that the acerola phytoplasma emerges from the same branch from the representative of the 16SrIII-F subgroup (Figure 3).

The phytoplasma was transmitted in $70 \%$ of the grafted acerola plants. The typical and conspicuous symptoms of generalized stunting, yellowing and shoot proliferation were observed 80-90 days after grafting (Figure 4). The presence of phytoplasma was consistently detected in $100 \%$ of the symptomatic plants and the disease was identified as acerola shoot proliferation (ASP). Molecular identification confirmed that the phytoplasma detected was a member of the 16 SrIII-F subgroup. Samples from grafted plants also showed negative results for the presence of virus in their tissues.

The constant detection of phytoplasma confirmed the initial presumption of its presence in acerola bushes. The detection level over $70 \%$ observed for symptomatic plants reinforced the concept that the symptoms were related to the presence of phytoplasma, since the

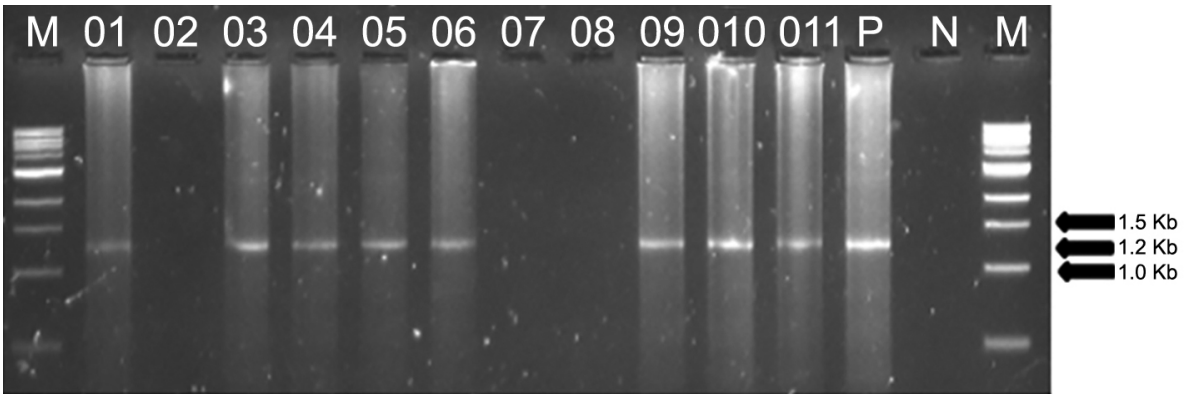

Figure 1 - Amplification of genomic fragments of $1.2 \mathrm{~kb}$ from 16S rRNA of the phytoplasma found in 8 out of 11 samples of the symptomatic acerola plants, using nested PCR primed by the pair R16mF2/mR1 followed by R16F2n/R2. Column: M- 1 kb Lader molecular marker; Columns: 01-011 samples of acerola; Column: $\mathrm{P}=$ Positive control (GenBank GU193977); Column: $\mathrm{N}=$ Negative control. 

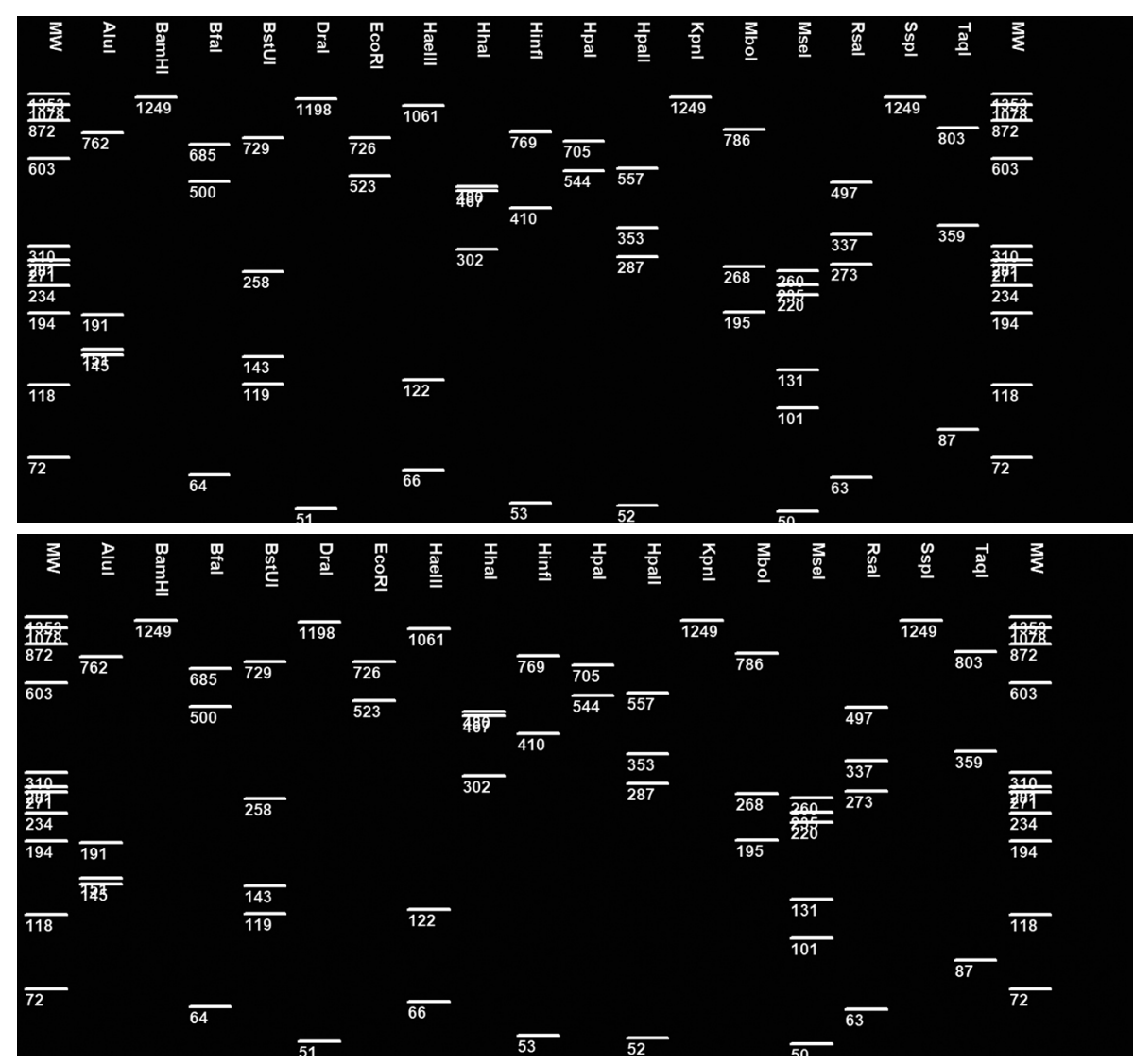

Figure 2 - Virtual RFLP patterns from in silico digestions of 16S rRNA gene R16F2n/R16R2 fragments from acerola phytoplasma (GenBank MT15359- Above) and from reference phytoplasma of the 16Srll-F subgroup (GenBank AF510724- Below). Molecular Weight: $\phi$ X174RFHaell digest.

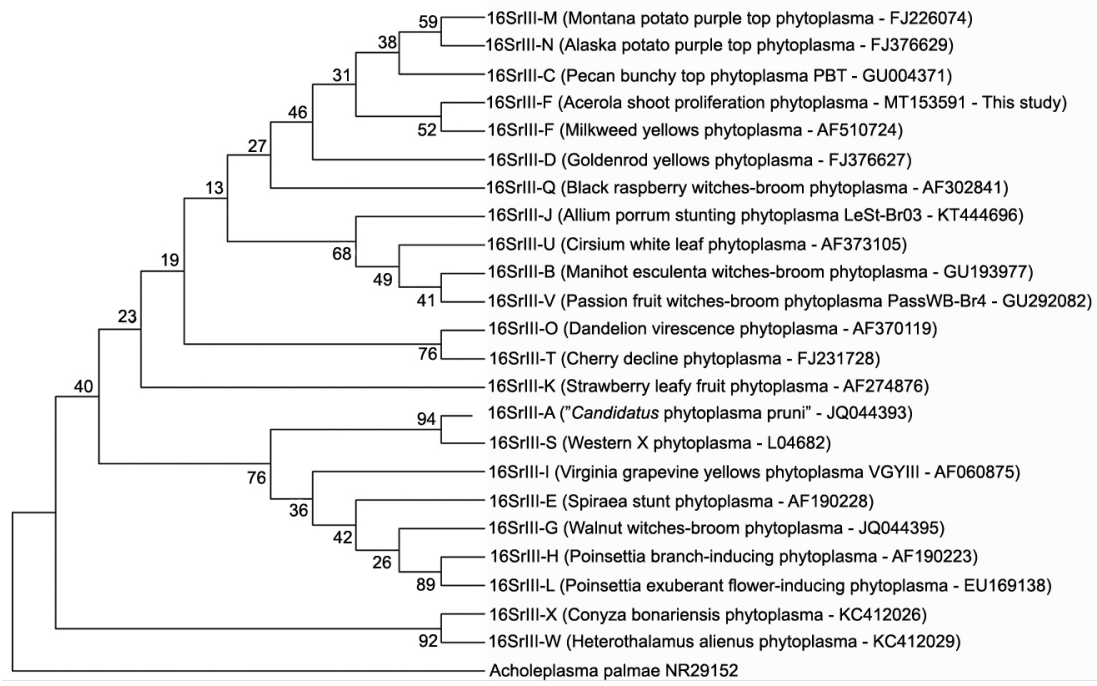

Figure 3 - Phylogenetic tree constructed with the sequence of the phytoplasma identified in the acerola plants (GenBank MT153591) and phytoplasmas belonging to subgroups of the $16 \mathrm{Sr}$ lll group.

virus was not detected in the samples. In addition, the preliminary suspicion that the disease was associated with the presence of an infectious agent was corroborated by a grafting experiment, which provided evidence where the phytoplasma occurring in the symptomatic bushes was transmitted by grafting to healthy plants. Moreover, 


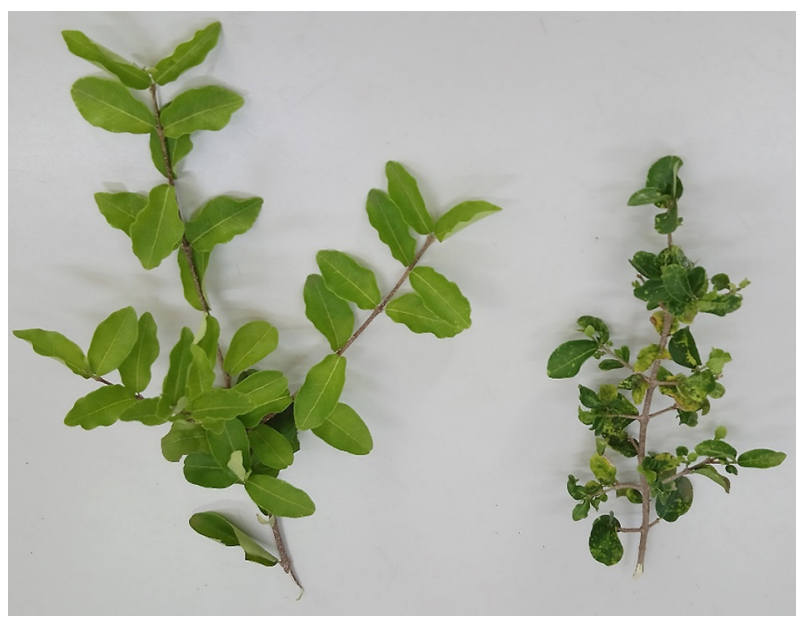

Figure 4 - Acerola healthy branch (left) and symptomatic branch produced by plant grafted with scions from naturally diseased plant (right).

the sequence of the $16 \mathrm{~S}$ rRNA gene confirmed that the same microorganism was present in naturally infected and grafted plants.

Studies on phytoplasmas have been carried out on numerous pathosystems in Brazil, indicating the occurrence of a broad range of hosts and pathogens. Surveys have revealed that the diverse representatives of the 16SrIII group are those most frequently found in cultivated and uncultivate species, such as Brassica oleracea (Rappussi et al., 2012; Eckstein et al., 2013; Amaral-Mello et al., 2011); Manihot esculenta (Flôres et al., 2013; Souza et al., 2014); Solanum melongena; Passiflora edulis, Cucurbita pepo, Sechium edule, Solanum licopersicum, Melia azedarach, Catharanthus roseus and Euphorbia pulcherrima (Amaral-Mello et al., 2011); Leonurus sibiricus (Flôres and Bedendo, 2013); Celosia sp. (Eckstein et al., 2012); Bougainvillea spectabilis (Silva et al., 2014); and Brachiaria decumbens (Fugita et al., 2017). Interestingly, the subgroup 16SrIII-F had not been reported in Brazilian territory. However, members of this subgroup were described inducing phyllody, stunting, yellowing, and abnormal growth in Heracleum sosnowskyi specifically in Lithuania (Valiunas et al., 2007), in H. sosnowskyi, Dictamnus albus, Vaccinium corymbosum, and V. myrtillus in various European countries, and in Asclepias syriaca in North America (Valiunas et al., 2004).

The findings of this study indicated that the disease is associated with a phytoplasma, acerola being a new host for a strain belonging to the 16SrIII group, and the first occurrence of a 16SrIII-F phytoplasma in Brazil. In addition, to the best of our knowledge, this is the first report of an acerola disease associated with the presence of a phytoplasma on a worldwide scale. As a result of demonstrating the association between acerola shoot proliferation and phytoplasma, two control measures are proposed: i) seedlings used for the initial establishment of commercial orchards which are produced by cuttings, are propagative material, represented by branches, that should be obtained from mother plants free of the pathogen and ii) although insect vector transmission is unknown, it is suggested that seedlings should be produced in protected nurseries, so as to avoid the entry of possible vectors.

\section{Acknowledgment}

The research was supported by the Brazilian National Council for Scientific and Technological Development (CNPq). Project 304268/2018-6.

\section{Authors' Contributions}

Conceptualization: Ferreira, J.; Pereira, T.B.C.; Bedendo, I.P. Data acquisition: Pereira, T.B.C.; Ferreira, F. Data analysis: Ferreira, J.; Almeida, C.A.; Pereira, T.B.C.; Favara, G. Design of methodology: Ferreira, J.; Almeida, C.A.; Bedendo, I.P. Software development: Ferreira, J.; Bedendo, I.P. Writing and editing: Ferreira, J.; Bedendo, I.P.

\section{References}

Amaral-Mello, A.P.O.; Eckstein, B.; Flôres, D.; Kreyci, P.F.; Bedendo I.P. 2011. Identification by computer-simulated RFLP of phytoplasmas associated with eggplant giant calyx representative of two subgroups, lineage of 16SrIII-J and new subgroup 16SrIII-U. International Journal of Systematic and Evolutionary Microbiology 61: 1454-1461.

Bertaccini, A.; Duduk, B.; Paltrinieri, S.; Contaldo, N. 2014. Phytoplasmas and phytoplasma diseases: a severe threat to agriculture. American Journal of Plant Sciences 5: 1763-1788.

Chang, S.K.; Alasalvar, C.; Shahidi, F. 2018. Superfruits: phytochemicals, antioxidante efficacies, and health effects; a comprehensive review. Critical Reviews in Food Science and Nutrition 59: 1580-1604.

De Rosso, V.V.; Mercadante, A.Z. 2005. Carotenoid composition of two Brazilian genotypes of acerola (Malpighia punicifolia L.) from two harvests. Food Research International 38: 1073-1077.

Doyle, J.J.; Doyle, J.L. 1990. Isolation of plant DNA from fresh tissue. Focus 12: 13-15.

Eckstein, B.; Barbosa, J.C.; Kreyci, P.F.; Canale, M.C.; Brunelli, K.R.; Bedendo, I.P. 2013. Broccoli stunt, a new disease in broccoli plants associated with three distinct phytoplasma groups in Brazil. Journal of Phytopathology 161: 442-444.

Eckstein, B.; Silva, E.G.; Bedendo, I.P. 2012. Shoot proliferation and leaf malformation of Celosia argentea and Celosia spicata caused by a phytoplasma of the 16SrIII-J group. Journal of Phytopathology 160: 206-208.

Flôres, D.; Bedendo, I.P. 2013. A subgroup 16SrIII-B phytoplasma identified in honeyweed plants with leaf deformation in Brazil. Australasian Plant Pathology 8: 59-62.

Flôres, D.; Haas, I.C.; Canale, M.C.; Bedendo, I.P. 2013. Molecular identification of a 16SrIII-B phytoplasma associated with cassava witches' broom disease. European Journal of Plant Pathology 137: 237-242. 
Fugita, J.M.S.; Pereira, T.B.C.; Banzato, T.C.; Kitajima, E.W.; Souto, E.R.; Bedendo, I.P. 2017. Occurrence of a subgroup 16SrIII-J phytoplasma in non-symptomatic Brachiaria decumbens cultivated in a grazing area. Tropical Plant Pathology 42: 500-503.

Gundersen, D.E.; Lee, I.M. 1996. Ultrasensitive detection of phytoplasmas by nested-PCR assays using two universal primer pairs. Phytopathologia Mediterranea 35: 144-151.

Ha, C.; Coombs, S.; Revill, P.A.; Harding, R.M.; Vu, M.; Dale, J.L. 2008. Design and application of two novel degenerate primer pairs for the detection and complete genomic characterization of potyviruses. Archives of Virology 153: 25-36.

Lee, I.M.; Davis, R.E.; Gundersen, D.E. 2000. Phytoplasmas: phytopathogenic mollicutes. Annual Review of Microbiology 54: 221-255.

Leffa, D.D.; Silva, J.; Daumann, F.; Dajori, A.L.F.; Longaretti, L.M.; Damiani, A.P; Andrade, V.M. 2014. Corrective effects of acerola (Malpighia emarginata DC.) juice intake on biochemical and genotoxical parameters in mice fed on a high-fat diet. Mutation Research Fundamental and Molecular Mechanisms Mutagenesis 770: 144-152.

Malembic-Maher, S.; Constable, F.; Cimerman, A.; Arnaud, G.; Carle, P.; Foissac, X.; Bouddon-Padieu, E. 2008. A chromosome map of the flavescence dorée phytoplasma. Microbiology 154: 1454-1463.

Rappussi, M.C.C.; Eckstein, B.; Flôres, D.; Haas, I.C.R.; Amorim, L.; Bedendo, I.P. 2012. Cauliflower stunt associated with a phytoplasma of subgroup 16SrIII-J and the spatial pattern of disease. European Journal of Plant Pathology 133: 829-840.

Rizos, H.; Gunn, L.V.; Pares, R.D.; Gillings, M.R. 1992. Differentiation of cucumber mosaic virus isolates using the polymerase chain reaction. Journal of General Virology 73: 2099-2103.

Rojas, M.R.; Gilbertson, R.L.; Maxwell, D.P. 1993. Use of degenerate primers in the polymerase chain reaction to detect whitefly-transmitted geminiviruses. Plant Disease 77: 340-347.
Silva, E.G.; Flôres, D.; Bedendo, I.P. 2014. Bougainvillea shoot proliferation a new disease induced by distinct phytoplasmas. Journal of Phytopathology 163: 872-876.

Silva, P.B.; Duarte, C.R.; Barrozo, M.A.S. 2019. A novel system for drying of agroindustrial acerola (Malpighia emarginata D.C.) waste for use as bioactive compound source. Innovative Food Science and Emerging Technologies 52: 350-357.

Souza, A.N.; Silva, F.N.; Bedendo, I.P.; Carvalho, C.M. 2014. A phytoplasma belonging to a 16 SrIII-A subgroup and dsRNAvirus associated with cassava frogskin disease in Brazil. Plant Disease 98: 771-779.

Tamura, K.; Stecher, G.; Peterson, D.; Filipski, A.; Kumar, S. 2013. MEGA6: molecular evolutionary genetics analysis Version 6.0. Molecular Biology and Evolution 30: 2725-2729.

Valiunas, D.; Alminaite, A.; Jomantiene, R.; Davis, R.E.; Maas, J.L. 2004. Possible cause of European blueberry disease is related to North American milkweed yellows phytoplasma. Journal of Plant Pathology 86: 135-140.

Valiunas, D.; Samuitiene, M.; Rasomavicius, V.; Navalinskiene, M.; Staniulis, J.; Davis, R.E. 2007. Subgroup 16SrIII-F phytoplasma strains in an invasive plant, Heracleum sosnowskyi, and an ornamental Dictamnus albus. Journal of Plant Pathology 89: $137-140$.

Wei, W.; Lee, I.M.; Davis, R.E.; Suo, X.; Zhao, Y. 2008. Automated RFLP pattern comparison and similarity coefficient calculation for rapid delineation of new and distinct phytoplasma subgroup lineages. International Journal of Systematic and Evolutionary Microbiology 58: 2368-2377.

Zhao, Y.; Wei, W.; Lee, I.M.; Shao, J.; Suo, X.; Davis, R.E. 2009. Construction of an interactive on line phytoplasma classification tool, iPhyClassifier, and its application in analysis of the peach $\mathrm{X}$ - disease phytoplasma group (16SrIII). International Journal of Systematic and Evolutionary Microbiology 59: 2582-2593. 